\title{
Post-structuralism, Complexity and Poetics ${ }^{\bullet}$
}

\author{
Michael Dillon
}

Michael Dillon is Professor of Politics and Director of the Institute for Cultural Research at the University of Lancaster. Co-editor of the Institute's journal, Cultural Values, he has also written extensively on continental philosophy, security and global liberal governance.

\footnotetext{
- This essay began life in the form of a presentation to an ESRC sponsored seminar on 'Complexity and the Social Sciences' at the Centre for Social Theory and Technology at the University of Keele. I would like to thank all the participants in that seminar but most especially Bob Cooper and Rolland Munro. I have longstanding debts to their intelligence and to their friendship. I would also like to thank Julian Reid from whom I take my bearings in respect of the strategic and Sarah Dillon from whom (this time) I have taken my bearings in respect of Beckett. Thanks finally to the referees on this paper. Their comments were as generous as their criticisms were acute.
} 
'Whatever you say, say nothing.' 


\begin{abstract}
Post-structuralism and complexity are plural and diverse modes of thought that share a common subscription to the 'anteriority of radical relationality'. They nonetheless subscribe to a different ethic of life because they address the anteriority of radical relationality in different ways. Complexity remains strategic in its bid to become a power-knowledge of the laws of becoming. It derives that strategic ethic from its scientific interest in the implicate order of non-linearity that is said to subvert Newtonian science. Post-structuralism is poetic. It derives its poetic ethic from Heidegger and from the re-working of orphic and tragic sensibilities to radical relationality with the radically non-relational. Observing that all poetry is complexity avant la lettre, the paper illustrates these points with the Odyssey and concludes that while complexity is ultimately concerned with fitness, post-structuralism is pre-occupied with justice.
\end{abstract}

\title{
Introduction: The Co-incidence of Post-structuralism and Complexity
}

My response to the terms 'post-structuralism' and 'complexity' is frankly Nietzschean. Only that which has never had a history, Nietzsche constantly reminds us, can be 'defined'. That is why he called those who think that they honour a thing by dehistoricising it, 'Egyptians'. They mummify it instead. "Nothing real," he says, 'escape[s] their hands alive." (Nietzcshe, 1997: 18). Since post-structuralism and complexity have had, and continue to display, a vexed and complicated history I do not intend to compare them by defining them. I nonetheless still do want to take the risk of differentiating between them. If we are to remain faithful to Nietzsche's insight, that difference must 
necessarily be concerned not with contrasting definitions but with how each exhibits their liveliness. That in turn means asking the question what disposition or ethos - what form of life - is exemplified and championed by them? In comparing them, therefore, it is not simply a matter of what we can know, and of better ways of knowing. It is a question of how we live, of how we may live and, increasingly perhaps also, of how we may continue to live. These are not simply my points. They are points continuously made by post-structuralists and complexity scientists themselves. Even, for the latter, in their most epistemologically committed moments; since those who champion the hegemony of epistemology, whatever the epistemology happens to be, always do so in the name of human betterment. Navigating between oversimplification and obfuscation here is a tricky business that recalls what Derrida once said in the course of his demolition of John Searle. "One shouldn't complicate things for the pleasure of complicating, but one should also never simplify or pretend to be sure of such simplicity where there is none. If things were simple, word would have gotten round.” (Derrida, 1988b: 119).

Any sensible account of post-structuralism will begin then by saying that it refers to such a diverse body of work and thought that it cannot be captured in a summary definition. The point is borne out by post-structuralism's genealogy. Among its sources are German Idealism, Romanticism and the advent of "Literature", the linguistic turn in Philosophy, the Saussurean turn in Linguistics, the 'destruktion' of metaphysics that followed the Kantian turn in philosophy (despite the fact there is no simple escape from metaphysics), and the work of deconstruction. It is commonly influenced also by what Michel Serres and Gianni Vattimo would call the advent of generalised communication 
and distribution (Serres, 1982; Vattimo, 1992), or what complexity scientists might call 'generalised reference' (Cilliers, 1998).

Yet, from its origins in this diversity of intellectual movements there are nonetheless positions to which so-called post-structuralist thinkers, albeit in radically different ways and for sometimes radically different reasons as well, might be said to subscribe. These include the following. The failure of onto-theology, over millennia, satisfactorily to establish the ground of Being (Nietzsche, 1983; Heidegger, 1968). The pervasive significance of Language in human existence (Heidegger, 1982; Derrida, 1976). The originary and fundamentally disordered nature of the logos (Nietzsche, 1989; Heidegger; 1985; Derrida; 1987). The related inevitable misfire of all enunciation (Derrida, 1976; Butler, 1997). The related and equally inevitable miscount of all accounts of the distribution of speaking bodies (Rancière, 1998). The radical relationality of bodies (Deleuze, 1988). The emergent property of bodies contingent upon the modes of relationality productive of and mediated by them (Foucault, 1985). Language as the other of all others, or the relation of foreignness as such: what Blanchot calls "the relation of the third kind" (Blanchot, 1993: 66). The temporality of being and the finitude of human existence (Heidegger, 1984; Agamben, 1991). To put it simply, that means death and its irreversibility. To put it more technically, and in Heideggerean terms, it means beingtoward-death (Heidegger, 1967). Hostility also in one degree or another to equating human existence and excellence with what Heidegger called the project of representativecalculative thought and the privilege it grants to epistemology over ontology and ethicality. Human existence, in contrast, understood as always already ethical. Ethical not understood here by reference to a command issued by some superior being or moral law. 
Ethical understood, instead, in terms of the ethos or way of being of things derived from their location within an inescapable matrix of relationality that is both diachronic as well as synchronic, temporal as well as spatial. Or what Deleuze called kinetic and dynamic, which is not quite the same thing either (Deleuze, 1988). The changing specification of bodies in terms of their bearings within a relational matrix (Dillon, 1996); contingent upon what Deleuze in his account of Spinoza also called their longitude and latitude, their kinetic and dynamic attributes and their capacity to affect as well as to be affected (Deleuze, 1988).

The longer the list of such subscriptions becomes, however, the more attenuated the links between them. The more attenuated the links, the more violence is also done to the reflections, positions and commitments of the philosophers most usually associated with post-structuralism: Heidegger, Levinas, Derrida, Blanchot, Lyotard, Foucault, Deleuze and Guattari to name but a prominent few of the usual suspects. Learning from their near contemporaries, and from each other, all these thinkers were deeply indebted also to different sources, and different combinations of sources, from within the wider tradition of western philosophy and science. Heidegger engaging Kant, Hegel, Nietzsche and Husserl, as well as Aristotle, Plato and the pre-Socratics. Derrida indebted to his readings of Plato, Kant, Hegel and Freud as well as Heidegger and Nietzsche. Foucault betraying his immersion not only in Nietzsche and Heidegger but also his indebtedness to Canguilhelm. Deleuze drew perhaps pre-eminently on Spinoza and Bergson. Levinas was indebted to the entire chiasmus of what Derrida called Greekjew/Jewgreek.

Such references as these are of course indicative. They do not in any way exhaust the range of influences to which these thinkers were indebted. Nor do they say anything 
about the different ways in which they combined their influences. Neither, finally, do I want to suggest that such thinkers were only influenced by philosophers or by science. They were not. Just as certain poetry (Trakl, Rilke and Holderlin) was important for Heidegger (Taminiaux, 1993; Foti, 1992), so also was 'Literature' and 'Writing' for Derrida, Blanchot, Foucault, Deleuze and others (Lacloue-Labarthe and Nancy, 1988; Critchley, 1997). You therefore quickly reach the point where it is the very the profound differences between such so-called post-structuralist figures that forces itself to the top of the agenda. Progress in terms of understanding and interpretation of their contribution to thought becomes critically dependent not only upon the ability to discriminate within as well as between their work, but also to recognise that they differ widely in terms of their very understanding of the project of thought itself. Contrast, for example, Heidegger, whose path of thinking at least after Being and Time (1967) was never directed towards the production of a philosophical system, with Deleuze whom some influential commentators maintain remained committed to precisely such a project (Patton, 1996). All these thinkers in some sense nonetheless also shared an interpretation of thought as constitutive rather than as simply representative. For them thinking was less about representing the real than it was with living it out in different ways. For that reason their 'real' always remained something radically different from that of representativecalculative thought. Think of Heidegger's 'pathways', of Levinas' 'ethicality', Foucault's 'molotov cocktails', or of Deleuze's 'concepts'.

Every account of complexity science also begins in precisely the same way. It, too, refers to such a diverse and developing body of thinking and research that mere definition of it seems bound to go wrong. "For some years," Isabelle Stengers wrote 
recently, "the theme of complexity has played an ambiguous role in discourses on science." (Stengers, 1997: 4.3). Moreover its genealogy while different from is in many ways also as diverse as that of post-structuralism. Deriving from physics, chemistry and non-linear maths it also includes the microbiolgical sciences, cybernetics, the study of turbulence and of systems in far from equilibrium conditions. Complexity, too, is nonetheless distinguished by a characteristic set of preoccupations. These include for example those concerned with dissipative structures, bifurcation, autopoiesis, complex adaptive systems, self-organisation and auto-catalysis. Just as post-structural influences migrated throughout the humanities and social sciences so also has complexity migrated through a number of the natural sciences on its way also into the management and social sciences and, I think critically, into digitalised information and communications technologies. From there in particular it has an established and increasing resonance also with changes in strategic thinking, military science, national and global governance, cultural governance and international politics (de Landa, 1991; Rosenau, 1992; Jervis, 1999; Alberts and Czerwinski, 1997; Cebrowski and Gartska, 1998).

\section{The Ethic of Post-structuralism}

The seductive, but misleading, coincidence of view between post-structuralism and complexity noted by many analysts (Cilliers, 1998) lies in what I propose to call their shared commitment to the "anteriority of radical relationality". The term 'radical' qualifies 'relationality' here in the following way. It means that nothing is without being in relation, and that everything is - in the ways that it is - in terms and in virtue of relationality. Post-structuralism and complexity both argue for this. More importantly 
they argue from it. That is to say they take radical relationality as their point of departure for the ramification of all sorts of enquiries and accounts of the natural and of the social world; better to say of the order of radical relationality since many would not subscribe to the traditional distinction between the natural and the social. That they do so does not however mean that they subscribe to the anteriority of radical relationality in exactly the same ways and for precisely the same reasons. That is the point. They do not. The anteriority of radical relationality is described differently, its implications have been pursued differently, and the entailments of the anteriority of radical relationality are embraced in different ways. More than anything else what distinguishes the two is this.

For complexity thinkers the anteriority of radical relationality is just that, an anteriority of radical relationality. They seek to understand the 'implicate orderliness' the orderliness as such even if the notion of order is developed in novel ways - of the anteriority of radical relationality (Bohm, 1980). For post-structuralists the anteriority of radical relationality is relationality with the radically non-relational. Here the radically non-relational is the utterly intractable, that which resist being drawn into and subsumed by relation albeit it transits all relationality as a disruptive movement that continuously prevents the full realisation or final closure of relationality, and thus the misfire that continuously precipitates new life and new meaning. There is no relational purchase to be had on the intractable. It resists relation. How is it therefore possible to be in radical relation with the radically non-relational? Yet we always already are. That is why Derrida refers to it as an (im)possibility or 'aporia' (Derrida, 1993). That we always already are is what fuels his current interest in, albeit also his reservations about, religion and faith (1998). This persistence of the radically non-relational in the relational will always 
confound any notion of final order. And that is why, according to post-structuralists, there will always be more ordering yet to come. As Levinas put it: "The alterity of the absolutely other is not an original quiddity of some sort... The Other is not a particular case, a species of alterity, but the original exception to the order." (Levinas, 1998: 12-13). For him the rupture of the radical relation with the radically non-relational is a profoundly exceptional relation that expresses itself in ethical terms. The distinction I offer seems to me therefore to be a fundamentally important one. It is the crux of the difference between complexity and post-structuralism. That is why, despite all the similarities of their common subscription to the anteriority of radical relationality, their ethos is ultimately so dissimilar.

It is also important to note that the non-relational is figured in many different ways by so-called post-structuralist thinkers. This is another way in fact of distinguishing between them. With the Heidegger of Being and Time (1962), for example, the nonrelational is figured as death. For Levinas the non-relational is the Other. For Derrida, the non-relational is that of Alterity, though he gives it many other names and explores its deconstructive force in many other contexts through the operation of differànce. For Lacan the non-relational is the Real. Despite the charge that all he sees is power, Foucault too noted that:

there is indeed always something in the social body, in classes groups and individuals themselves which in some sense escapes relations of power, something which is by no means a more or less docile or reactive primal matter, but rather a centrifugal movement, an inverse energy, a discharge. (Foucault, 1980: 138). 
Each of these starting points also gives rise to different projects and that is why, amongst many other reasons, there is no single school of thought here sensibly encapsulated by such terms as post-structural or post-modern. There are many different ways of thinking "the Other-in-the-Same [L'Autre-dans-le-Même] without thinking the Other [l'Autre] as another Same [Même'].” (Levinas, 1998: 80).

Heidegger's project, initially at least, was a fundamental ontology capable of sustaining a project of authenticity. Later he found radical relationality in relation to the radically non-relational to be the special preserve of the poetic. Levinas' project was an infinite ethicality that was, conversely, hostile to claiming a privileged place for the poetic: "Cutting across the rhetoric of all our enthusiasms, in the responsibility for the other, there occurs meaning from which no eloquence could distract - nor even any poetry." (Levinas, 1998: 13). In this however he was resisted by Blanchot who noted how much Levinas distrusted poetry and marked it as one of those things amongst others that had to be overcome if there was to be 'ethics' as first philosophy. Conversely, for Blanchot, only in virtue of the radical exteriority opened up by the 'experience of Language' does such a thing as an ethical relation become possible. (Blanchot, 1993). Derrida's project displays similarities and difference with both these projects since his pre-occupation is also that of an inescapable and infinite responsibility ramified especially in terms of justice and of undecidability. Lacan's, however, was a revised psychoanalysis disclosing the structure of desire while Jacques Rancière figures the nonrelational as "a magnitude that escapes ordinary measurement." (Rancière, 1999: 15). Rancière's project is a much more explicitly theorised account of the political as a 
relation that is formed by this radical relation with the radically non-relational that he figures as a paradoxical magnitude which simply does not add up.

It is nonetheless the very coincidence of subscription to the anteriority of radical relationality that prompts me to question the relation between post-structuralism and complexity in the way that I do: What ethic does post-structuralism or complexity science call into play, and call upon? By ethic I do not mean of course the traditional command ethic of onto-theology (Connolly, 1993). I mean, recalling the point made earlier, ethic in the Greek sense of the term. That is to say, ethic in terms of ethos or form of life that is both presupposed and enacted in living. As John Caputo put it:

On the view I am defending ethics is always already in place, is factically there as soon as Dasein, as soon as there is world. Ethics is not something that fitted into a world that is somehow prior to it. Ethics constitutes the world in the first place....If you want to think what truly 'is' you have to start with ethics and obligation, and not add it on later. To put it in terms that I would prefer, the space of obligation is opened up by factical life, by the plurality of living bodies, by the commerce and intercourse of bodies with bodies, and above all, in these times of holocaust and of killing fields, by bodies in pain - but no less by thriving and flourishing bodies, by bodies at play. (quoted in Dillon, 1996: 62).

Deleuze makes the same point but in a different way. In concluding his account of Spinoza's thought, differentiating between the plane of transcendence and the plane of immanence while siding with the latter, Deleuze continuously insists on the ethicality involved. 'To be in the middle of Spinoza,' he says, 'is to be on this modal plane' of 
immanence. He then corrects himself. Or rather, he says, it is 'to install oneself on this plane - which implies a mode of living, a way of life.' (Deleuze, 1988: 122). And, in exploring how radical relationality leads to an entirely different understanding of 'bodies' and their properties in terms of how their 'capacity for affecting and being affected...defines a body in its individuality,' he insisted that in addition to it now being: a question of knowing whether relations (and which ones) can compound directly

to form a new more 'extensive' relation, or whether capacities can compound directly to constitute a more 'intense' capacity or power. It is no longer a matter of utilisations or captures, but of sociabilities and communities. (Deleuze, 1988: 126, emphasis added).

A recent collection of essays by Isabelle Stengers makes my point in respect of complexity thinkers as well. 'The response to the question of complexity' which she insists is not discovered but is integrally to do with a discourse about science, Stengers says, 'is not theoretical but practical. It requires what Jean-Marc Levy-Blond called the enculturation of science.' (Stengers, 1987: 18.9). Ethics is not then counter-posed here to technique. It incorporates technique insisting that different techniques themselves entail different ethics or ways of being: as scientist; as poet; as politician; as thinker; as teacher; as lover; as parent and so on.

The very vocabulary of complexity science, and its preference for the terminology of systems in particular, together with its necessary preoccupation with the boundary of systems rather more than the liming of liminality, signals however a much more strategic disposition amongst complexity thinkers than amongst post-structuralists. This is the crux of the difference in approaches since so much post-structuralist thinking remains heavily 
indebted to Heidegger's account of the age of the world picture and his corresponding indictment of machination, instrumentality and what he generically describes as 'technology' (Heidegger, 1977). Conversely much complexity thinking remains indebted to the modern project of science, however much it seeks to distance and differentiate itself from Newtonianism (Nicolis and Prigogine, 1989). It is nonetheless important to register a caveat here in respect of post-structuralism. It is one that confirms a point made above about the diversity of post-structuralism and complexity. Not all of those who accept the philosophical significance of Heidegger, for example, would subscribe to his account of technology and 'Ge-stell' (Heidegger, 1977). Bernard Stiegeler's recent work is a particular case in point (Stiegeler, 1998). The originary technicity of human being together with its radical relationality also prompt some like Deleuze to challenge the traditional distinction between the human and the non-human, the natural and the artificial, in ways that significantly diverge from Heidegger.

In arguing that different ethics are at issue here - the poetic and the strategic - I invoke an argument more complicated than I will be able to develop in full since it relies on an account of the poetic that is indebted to Heidegger and to the pre-Socratics (Dillon, 1996). This qualifies the traditional Aristotleian distinctions between poiesis and praxis (which is why, amongst other reasons, Heidegger speaks instead of Dichtung), while nonetheless continuing to recognise that the poetic is a form of making (Taminiaux, 1977; Bernasconi, 1985; Villa, 1997). As a form of making it is however a form of disclosure of radical relationality in relation with the radically non-relational (Heidegger, $1971 \mathrm{a}$ and b). I find a powerful poetic indebtedness in post-structuralism inherited in part but not exclusively from Heidegger that contrasts, then, with the powerful strategic 
commitments of complexity. No doubt the reasons for this contrast lie deep in their different genealogies. But its persistence is what fundamentally differentiates the two despite their common commitment to the anteriority of radical relationality, to the dynamic and mobile nature of existence and to the contingent and shifting character of what I propose to call the bodies-in-formation of radical relationality. Somehow, given complexity's pre-occupation with code and post-structuralism's pre-occupation with Language, that difference also concerns their different dispositions towards the sign.

\section{The Ethic of Complexity}

The anteriority of radical relationality means the following and ramifies in the following ways for complexity thinkers. Despite the internal differences that characterise it, despite the hyperbole of those evidently seeking to effect a new scientific and managerial ideology out of complexity science there is a shared commitment to two key perspectival shifts in respect of the project of science itself. These two key moves are intimately related and the outcome of their conjunction - epistemologically, or at least in terms of the knowledge or intelligence that they seek - is profound. They concern the two essential ways in which science describes and accounts for the natural world. The one concerns taxonomy, and the other concerns relationality as such.

Traditional epistemic forms, according to complexity thinking, are Newtonian and taxonomic. In brief, and to use a compound term that nonetheless dangerously conflates a large and diverse field, what complexity theorists call 'Newtonian Science' conceives of pre-formed bodies found to be operating in mechanical relations and processes of exchange. Temporality here is a parameter, rather than an operator. Said to be unaffected 
by the transformations that it describes (Prigogine, 1980: 3), Newtonian Science was also based upon a naïve realism which assumed that the properties of matter were 'there' independent of the experimental devices by which they were observed, and recorded as existing (Prigogine, 1980: 215). The assumption of pre-formed bodies is the key link between the Newtonianism of traditional epistemic structures and their reliance, in addition, on secure taxonomic schemas. Taxonomy too, of course, shares the assumption of pre-formed bodies. It is the function of taxonomic science - take zoology for example reliably to assign natural bodies to appropriate categories and classifications; assuming also that the world is pre-inscribed with the natural order mapped by taxonomy. It follows that should a mode of relating in time that is not merely mechanical, or confined to exchange, and that allows time to be an operator rather than just a parameter, is allowed, then the status of bodies and their formation will come into question. Similarly, but conversely, it follows that should bodies (organs, molecules, plants, animals, humans, hybrids of human/non-human form) arise that are anomalous, or 'monstrous', that is to say 'radically disordered' and intractable to secure classification, then the scientific adequacy of taxonimisation itself, and not just any individual taxonomy, is called into question (Foucault, 1980; Ritvo, 1998).

Fundamentally, complexity science makes both claims. In prioritising the mode of relating, accepting that temporality is an operator rather than a mere parameter, and conceiving of 'bodies' in terms of the contingent assemblages and ensembles (systems) that are a function of a mode of relating, it simultaneously subverted the epistemic structures upon which both Newtonian physics and the great scientific taxonomic enterprises of the last two hundred years proceeded. That is why - and how - the 
science(s) of complexity, it is claimed, now challenge the hegemony of these classical scientific enterprises. Stable taxonomy and mechanical predictability are thus displaced by the rationalities and problematics of the composite sciences of what I call 'being-information'. Here too 'information' or 'code' becomes the prevailing term and form of art. Now, advances in biology and in molecular science in particular (the contemporary life sciences) not only do offer ways of conceiving of modes of relation (infiltration; distribution; infection; contamination; mutation; colonisation; symbiosis) that are not simply mechanical ones of exchange, and in which temporality is an effective operator rather than a mere parameter, they also offer accounts of bodies that defy secure taxonomic classification. Since, as a function of modes of relation, such bodies are contingent assemblages - bodies-in-formation - rather than pre-formed entities. Biology, particularly at the microscopic rather than the macroscopic level - but, with genetic engineering, even there also - therefore offers a description of astonishing fecundity, mutability, motility, and sheer creative transformation and change that defies the macroscopic entropy of Newtonian science and the exhaustive taxonomies of classificatory schemas alike. Bacteria, for example, trade variable quantities of information in the form of variable quantities of genes with virtually no regard for species barriers, while new forms and modalities are propagated across species boundaries with almost indecent speed. Morphogenesis cannot be described or explained within the terms of the linear paradigm of pre-formed bodies in the predictable entropic motion of a logic of strategically determined succession. However, according to one exponent: "It has to be understood that what is not deterministic need not be random. The solution is the existence of a new type of causality." (Kempis, 1991: 257). How to understand that 
'causality', and its allied notions of pre-diction and pre-monition, is a key issue closely related to the ways in which the complexity sciences not only understand processes of formation and change but also those of creativity; how things happen, how they can be made to happen, and how matters can be construed so that certain kinds of happenings are encouraged or discouraged.

Prigogine's non-linear mathematics makes the claim that it is producing the mathematical formulations that lead to a unified picture that 'enables us to relate many aspects of our observations of physical systems to biological ones.' (Prigogine, 1980: xiv). Consequently, just as the concepts, dynamics, modes of analysis and metaphorics of bio-philosophy and biotechnics have begun radically, and extensively, to supplant those of mechanics and taxonomics, so also Prigoginean mathematics claims to complement their insights and to offer a means, 'not to 'reduce' physics and biology to a single scheme, but to clearly define the various levels of description and to present conditions that permit us to pass from one level to another.' (Prigogine, 1980: xiv).

Although I would argue forcefully against conflating his project with that of complexity, one of the single most powerful metaphor for distinguishing between Newtonianism and its competitors in bio-philosophy and complexity has been provided by the French philosopher Gilles Deleuze. It is an especially important one since it also serves to open-up debate with as well as within evolutionary thinking as well; something that inevitably comes to the fore once the shift to bio-philosophy is made. For Deleuze, the strategic order presumed by Newtonian science and taxonimisation alike would be said to be 'arboreal': (think trees). The self-propagation to which complexity science refers would be said to be 'rhizomatic': (think grass, lilies or bamboo). As opposed to 
traditional phyletic lineages, rhizomatic lineages serve to demonstrate the extent to which exclusively filialtive models of evolution are dependent upon exophysical system descriptions that are simply unable to account for the genuinely creative aspects of evolution. If the organism is a function of the frame within which the science of biology encodes it, then it is necessary to recognise that the frame captures only a small part of the possible information (and in-formation) that the assemblages are able to express, and of the creative potential immanent in the system. The existence of a code simultaneously requires a process of de-coding. Hence there is no genetics, for example, without genetic drift. Symbiosis, especially, serves to show that the delineation of organic units, such as genes, plasmids, cells, organisms and genomes is a tool of a certain mode of investigation as well; not an absolute ideal or model (Kay, 1993). This challenges notions of pure autonomous entities and unities because it functions through assemblages (multiplicities made up of heterogeneous terms) that operate in terms of cross-fertilising alliances rather than tight genealogical filiations of more or less scrupulous linear descent. A clear establishment of distinct 'kingdoms' - in the human as well as the non-human world - is rendered problematic. What become important, instead, are the relational order and its creative propensities.

Symbiosis similarly challenges the notion of informationally closed systems and corresponds as well to the rhizomatic rather than the arboreal model. Since codes are modes of mediation - in effect modes of transversal communication because there is no code without its corresponding de-coding - they are strictly speaking 'paralogical': para being the Greek prefix for alongside, besides, between, or in the midst of (Dillon, 1995). There is, in short, no tree life characterised by an increasingly differentiated genealogy, 
but a rhizome of spontaneous propagation occurring at diverse sites of spontaneous local creativity amenable to paralogic understanding (Taylor, 1995). Rhizomising a structure for example that of an organisation - would be designed to maximise this propensity for creative adaptation at local sites (Chia, 1994; 1995; and 1996).

What is more, however, such bio-philosophical forms of understanding and description seem for many best suited also to comprehending the transformations occurring with the global digitalisation of information and communication and the vast powers of propagation that characterise these developments as well. What biotechnics and complexity share with information and communication technologies is, then, a shift from a preoccupation with physical and isolated entities, whose relations are described largely in terms of interactive exchange, to components 'in-formation', as well as components of 'information'. The structures of such components are decisively influenced by the mode of relation governing their connectivity with each other and their 'environments'. In consequence of that dynamic connectivity, they display autonomous powers of adaptation, formation, organisation and spontaneous emergence. Connectivity, then, is a continuous process of being complexly enfolded in ways that simultaneously also spontaneously produce the unfolding of 'form'; 'form' of diverse and changing shape. What that disseminates in turn is that bio-philosophical discourse which these sciences tend to share; and a corresponding shift from the paradigms of the mode of production to those of the mode of code (Poster, 1992 and 1996; Bogard, 1997).

The very character of the mode of relating is, then, an active process of individuating the component parts in relation. Thus an individual component does not possess a unity in its 'identity'; that of the, presumed, stable state within which no 
transformation, or only linear transformation, is allowable. Rather, a component, or part, has a transductive unity. What that means is that it can pass out of phase with itself, break its own bounds, unfold its own potential. This capacity of becoming is an integral dimension of the component in a mode of relating, and not something that happens to it following a succession of events effecting something thought to be already fully given and present. Individuation is the process of change to which the component is subject in virtue of its very participation in a mode of relating. It is the becoming of the entity, not an exhaustion of its signification. What goes for machinic assemblages applies also to individual 'subjects' and 'bodies' of whatever description.

Here, while the world seems more viral and mutable than it does mechanistic and entropic (Ansell-Pearson, 1997b): "If the word "nature" is to retain a meaning, it must signify an uninhibited polyphenomenality,' of manifestation (Rabinow, 1996a:108). Finitude as empiricity gives way, also, to an 'unlimited-finite' play of forces and forms, the best example of which is DNA. An infinity of beings can and has arisen from the four bases out of which DNA is constituted. The Nobel Prize-winning biologist, Francois Jacob, makes the same point when he writes: 'A limited amount of genetic information in the germ line produces an enormous amount of protein structures in the soma...nature operates to create diversity by endlessly combining bits and pieces.' (Rabinow, 1996a: 92).

The mode of relation not only differentiates components; it also combines and recombines them in novel ways to produce new form. In effect it continuously demands the re-engineering of components themselves. Add temporality as an operator rather than parameter to all this, and all modes of relation must henceforth also be conceived as in 
motion. Together with the character of the mode of relating, it is also that temporal dynamic - an integral motility - which ensures that a mode of relating cannot leave the structure of components unaffected. Relationality, or in complexity terms, connectivity, is, must be, transformatory. The power play of relationality - and it is a power play, a point to which I return below - is then conceived as a productive flow, displaying different forms of motion - speed; velocity; waves; continuous flow; pulsing; fluidity and viscosity; rhythm; harmony; discordance; and turbulence - as its 'in-formation' incites the formation, deformation, reformation, mutation and transformation of contingent assemblages and complex 'life-in-formation'. No party to a relation is therefore a monadic, or molar, entity. Each is, instead, a mutable function of the character of the mode-of-being-related and its capacity for relationality.

Our traditional epistemic assumptions once also made it difficult for us to recognise that complex life forms can be made-up of inorganic as well as organic material since the machine has been classically defined in contradistinction to the organism. We now know that this is not so. 'Machines' - like the Internet - exist which do not have the governance organisms were thought to possess and yet are also powerfully capable of self-adaptation and self-propagation. We also know that it is possible to produce 'cartographies' of machinic assemblages in novel ways that show how the Kantian distinction between the organic and the non-organic breaks down. For all its apparent common sense, the strict partition between the organic and the non-organic rests on an ontological privileging of the notions of pre-formation, unity and finality that simply cannot be sustained now either in the ontological (that is to say, philosophical) or historical (that is to say, 'material') terms generated by the privileging of the anteriority of 
radical relationality. Even the ultra-Darwinian, Dawkins, has conceded that the concept 'organism' is of dubious utility precisely because it is so difficult to arrive at a satisfactory taxonomic classification and definition of it. Everything depends upon the hierarchy of life one is trying to defend. Thus the 'organism' enjoys a semiotic status, and cannot be conceived independently of our cognitive mapping of systems and their boundaries. It is possible, therefore, to conceive of machinic life, as Deleuze for example does, in terms of the evolution of 'becoming' in which non-organic life exists and through which it mutates. The evolution of machinic assemblages does not, then, refer specifically and exclusively to human contrivances and tools, but to peculiar modes of propagation, such as symbiosis and contagion, which in fact conflate the human and the non-human, as they do the organic and the non-organic. It is as mistaken on this view then to conceive of machines naively as single entities whose individuated existence is pre-given (AnsellPearson, 1997a; and, 1997b), as it is to think of the human without the originary technicity that even its reliance on signification indicates (Stiegeler, 1998). Going beyond the twin traditional arguments that organisms are either only more perfect machines, or that machines are never more than mere extensions of the organism, we arrive at the threshold of the sciences of dynamic living assemblages in which the traditional ways of distinguishing human and non-human, organic and non-organic, break-down; as does the related way of privileging components over the modes, and intensities, of relation in which they are found.

Having to relate - openness to intervention - is, therefore, invariant for all forms of life. That does not mean that life forms are determined in advance. On the contrary, it is the inescapable condition of complex patterns of auto-poiesis in which both 
relationality and component change. Being-in-formation, necessarily entails deformation, reformation, mutation and transformation. That is to say being-in-formation is characterised by gaps, misfires, breaks, slippage, unintended outcomes, transference and change. These cuts and breaks are not simply 'unauthorised' transversal communications within and between assemblages or systems that bring novel forces and relations into play and so also new formations. They are also a function of the way events occur which is not rule governed; or where the rule does not apply. Such movement takes place not simply as transfer and exchange but also as 'dissipation', 'dispersion', 'attenuation', 'infection', 'contamination', 'invasion', 'colonisation', 'mutation' and so on. That is to say, the involuted (feedback) connectivity of the system is a measure of its very liminality. Sustaining diverse kinds of alterior relations, this then manifests itself as bifurcation, singularity and phase transition. Opposed to this view is the ideal of systems implacably closed in on themselves striving to maintain an illusory autonomy, equilibrium or 'survival', by expending vast resource on specifying everything that is foreign to the system so that it can be regulated, expelled or kept from it. The price of such 'autonomy', or autarchy, is paid in terms of a self-destructive diminution of the liminal capacity of the system's connectivitiy.

\section{The Strategic}

The thrust of this kind of thinking nonetheless remains heavily strategic. It primarily conceives of itself as providing a more accurate and more empowering account of the natural world even as it includes the human in that world and conflates the very distinctions between the natural and the artificial. Complexity sciences do not therefore 
eliminate the human. Rather they are in danger of enacting a new strategising account of it, with the important distinction that what is offered is strategising without a strategiser. Power derives here from aligning oneself with the force of the law of becoming, rather than with some sovereign monopolising of 'being the law'. The force of the law of becoming for complexity is what Giorgio Agamben would call the force of a law without significance (Agamben, 1998).

These points require a short excursus through a post-structural account of power. The very manoeuvre registers a difference between complexity and post-structuralism since complexity thinking is itself vulnerable to what post-structuralism has told us about the complex character of modern power and of the discursive formations of powerknowledge of which much complexity thinking may be said to be another example. Whereas power-knowledge requires a 'thinking politically' in respect of its discursive formations complexity tends towards ramifying that 'control', in the Deleuzean sense of the term (1992), which power-knowledge seems impelled to seek. By strategic I mean preoccupied with continuous capacity to intervene in the orchestration of the play of objectification and subjectification by means of which the bodies-in-formation of beingin-relation come in and out of formation. By 'thinking politically' I mean the capacity to challenge and resist what the objectifications and subjectifications of the complex of power-knowledge, including also of course the power-knowledge of complexity, make of the human and its worlds. Such 'thinking politically' must have a strategic dimension to it, as Foucault for example observed when he noted 'the lack of a strategic analysis appropriate to political struggles in the field of political power.' (1980: 145). It requires a strategic intelligence able to 'analyse the specificity of mechanisms of power, to locate 
the connections and extensions, to build little by little a strategic knowledge.' (1980: 145) But it is not exhausted by that requirement. To what extent and how it may also need nurturing, for example, by the poetic sensibility to which I will turn next is however an intimately related and difficult question posed by post-structuralist modes of thinking. Foucault differentiated traditional accounts of sovereign juridical power from the ways in which modern power is more generally experienced. Sovereign power is hierarchical in a classically arboreal way concerned with the application of a law to an object. It flows down and out from a central sovereign source, or up and out from a tap root. If its primary manifestation is the establishing and executing of laws and regulation, its primary form is prohibition. The primary purpose of prohibition is that of preventing the illegal or the immoral always already identified in the original specification of the rule of law itself. Accompanying this account of power is an allied account of freedom. Since arboreal power is primarily concerned with the exercise of constraint, the freedom associated with it is escape.

In contesting this account of power, Foucault offered what he called a strategical analysis of power. By that he meant this. Power does not radiate from a prior conscious intentionality - that of a pre-formed sovereign body. It is understood instead in terms of formations of relation that are amenable to manoeuvres that have specifiable productive effects in terms especially of objectification and subjectification. That is to say - in the language of complexity - it has specifiable effects in terms of the production of contingent assemblages and ensembles, or what I have termed bodies-in-formation. 'Between every point of a social body,' he noted, 'there exist relations of power which are not simply a projection of the sovereign's greater power over the individual.' They are 
instead, he says, 'the concrete changing soil in which the sovereign's power is grounded, the conditions which make it possible for it to function.' (Foucault, 1980: 187). One of the primary effects of power as a strategising of relationality is indeed the very production and positioning of the intentionalities (subjects) that are then said to exercise it. Such power presupposes the 'freedom' of those it simultaneously subjectifies and (dis)empowers.

Complexity thinking is vulnerable to such a Foucauldian account of power since in like manner it endorses the operation of the power-knowledge of being-in-relation that is thereby also being-in-formation and seeks the means of its orchestration by allying with the force of the laws or dynamics of becoming. In like manner, too, especially in its appropriation via management, social and military sciences, it endorses the point that all power, as strategising-relationality, presupposes a life that bears the ordering work of power itself: whatever ways in which the bodies-in-formation of that life are conceived. It is only in as much as it does in fact presuppose such a life that power as strategy institutes itself as a specific and manifest productive ordering of life.

The key point to make about the operation of power as strategy, however, is that it is constrained to reproduce a life that is amenable to its sway. It must do so in order continuously to be instituted as a strategic ordering of life. That does not mean that it must insist on any specific definition of life. Quite the contrary in fact. But it must insist on an account of life fundamentally as malleable material that is available for and amenable to being strategised. While the life that power as strategy presupposes is therefore a life that is radically relational and free, and that only such a life is in fact capable of bearing the positive productive ordering of power as strategy, a strategic 
relation to that life nonetheless reduces the possibilities of its radically relational freedom. It must do so, and it does do so, in the process of construing life as that utile material required for the ordering strategy by which such power institutes, disseminates and reproduces itself. Here as we shall see the post-structuralist response is that - one way and another, and the ways differ - there is an excess of being over appearance however much that appearance is figured in terms of the non-linear laws of connectivity and becoming. In short for post-structuralist thinkers, not only is there more to life than meets the eye, that 'more' is never something that will ultimately make its appearance in the domain of representation. It is the intractable always already at work within but resistant to representation. Its presence-as-absence spoils the show for representation since it is always already subverting representation's productions.

In thus re-figuring power Foucault also reconfigured freedom. Since he no longer took power simply to be repressive prohibition, freedom was no longer conceived by him as an escape from it. In a curious sense, but a sense shared by many post-structuralist thinkers deriving very much also from Heidegger's conception of 'the openness of being', this 'freedom' is anterior to everything else. It is the undefined openness of existence itself. Resistance not freedom, then, is opposed to power in Foucault. Thus far from denying the possibility of freedom, Foucault's strategic account of power relations actually entails - a priori - freedom as a condition of possibility of power. It is the medium through which it courses, the field upon which it inscribes form as a particular order of freedom. Resistance is therefore freedom expressing its very intractability to the specific effects and strategising manoeuvres through which power orders it into specific if historically contingent formations. Just as power's strategising courses through many 
capillaries and traverses many terrains or topoi of encounter, for Foucault, so also resistance for him is equally disseminated and plural. Hence, too, Foucault's allied account of criticism as:

...historical investigations into the events that have led us to constitute ourselves and to recognise ourselves as subjects of what we are doing, thinking, saying. In that sense, this criticism is not transcendental, and its goal is not that of making metaphysics possible....it will separate out, from the contingency that has made us what we are, the possibility of no longer being, doing, or thinking what we are, do, think... it is seeking to give new impetus, as far and as wide as possible, to the undefined work of freedom. (Foucault, 1997: xxxv, emphasis added).

Freedom is an undefined work because it is an 'event'; something taking place with and in the opening of the radical relation with the radically non-relational which one way and another has therefore to be taken-on (Dillon, 1996).

These points could be developed in a variety of ways. I will confine myself to one further elaboration by reference to Deleuze. In re-telling, and retailing, his Spinozan account of philosophy and power, Deleuze relates how the science of Ethology accords with the being-in-formation of bodies-in-formation. If you define bodies and thoughts as capacities for affecting and being affected by virtue of their radical relationality or connectivity, many things, he says, change. You will, for example, define an animal, or a human being, not by its form, its organs, and its functions, and not as a subject either. You will define it by the affects of which it is capable. Hence his notoriously opaque but, in fact, perfectly clear and consistent idea of a body without organs. Since his idea of a body is determined by the capacities of relationality productive of beings-in-formation, 
not a pre-formed composite of assembled parts or organs, it follows that it is a body of relational capacities or capacities to be related - the powers to affect and to be affected rather than organs.

He goes on to note that Ethology studies the compositions of relations or capacities productive of and distinguishing between different things. A body, complexity thinkers would be much more likely to say a 'system', is never separable from its world. Hence: 'The interior is only a selected exterior, and the exterior, a projected interior.' (Deleuze, 1988: 125). It is, then, the combination of the speed or slowness of metabolisms, perceptions, actions and reactions that constitutes the individuality of the body-in-formation that is being-in-relation. Ethology studies, 'the relations of speed and slowness for affecting and being affected,' that characterise the being-in-relation of bodies-in-formation because each of these things, he explains, has an amplitude:

'thresholds (maximum and minimum) and variations or transformations that are peculiar to them.' (Deleuze, 1988: 125). A further point I would make is that such thresholds are precisely also thresholds of force and conflict because they are power points where the resistance of freedom manifests itself. It is there, I suggest, that the force of the 'laws' of becoming-formed encounter the resistance of a freedom that exceeds them and that, to use a military term, the reverse salients of that troublesome freedom intrude into the power of the being-formed of being-in-relation.

\section{$\underline{\text { The Poetic }}$}

Language is a sign system of radical relationality. As all thinkers influenced by postructuralist modes of thought also attest, Language is a system of radical relationality 
whose very liveliness is a function of the duality it displays by virtue of always already also being in indissoluble relation with the radically non-relational. In Beckett, for example, this is what makes being-in-language hesitate. It stammers and stutters but nonetheless persists...

you must go on, I can't go on, you must go on, I'll go on, you must say words, as long as there are any, until they find me, until they say me, strange pain, strange sin, you must go on, perhaps its done already, perhaps they have said me already, perhaps they have carried me to the threshold of my story, before the door that opens on my story, that would surprise me, if it opens, it will be I, it will be the silence, where I am, I don't know, I'll never know, in the silence you don't know... (Beckett, 1997: 418).

It is what also prompts Derrida to observe that 'Babelization does not therefore wait for the multiplicity of languages. The identity of a language can only affirm itself as identity to itself by opening itself to the hospitality of a difference from itself or of a difference with itself.' (1993:10). Language comes always already therefore divided, in relation with the radically non-relational, because of the intractable supplementarity that it harbours within itself without which it could not in fact bear - discharge - its very task of 'repetition' (Derrida, 1976): ‘ ...you must go on, I can’t go on, I'll go on...' (Beckett, 1997: 418).

This insight ramifies in all sorts of ways throughout so-called post-structuralist thinking. But it finds its expression especially through post-sructuralism's poetic sensibility. We are dealing here not with poetics as if there were a single poetics or understanding of poetry but with what Gerald Bruns calls the radical thesis of modern 
poetry, 'namely the idea that a poem is made of words, not of images or meanings.' (Bruns, 1997). Words that come enfolded in a manifold of references. It is a thesis that nonetheless comes indebted also to Heidegger and via Heidegger to his reading of the tragic and the pre-Socratics (Dillon: 1996). Its poetic sensibility is one in which a certain experience with language resists the codifying characteristic of all systems of signification and gives rise to something else: an experience with speechlessness, meaninglessness, or that in the sign intractable to the sign. Poetry here is the experience, and the expression, of resistance to code rather than complexity's strategic engagement with and attempted exploitation of code even in its non-linearity. Where the one (complexity) continues the quest of commanding the sign through making it work for us, albeit perhaps in new and newly productive ways, this poetic word seeks always to speak the irreducible to signification so that our relation to the sign and to Language as such and therefore our bearing as beings-in-language - is radically altered and re-figured. Heidegger calls this, 'undergoing an experience with Language, [in which] Language itself brings itself to Language.' (Heidegger, 1971a: 59). For Gadamer and Heidegger alike philosophy shares the defining project of the poetic: 'shaking up, extending, and throwing light on the horizon of communication.' (quoted in Bruns, 1987: 11).

This radical thesis of modern poetry is not a thesis that poetry is unintelligible, but that the poetic is an event that takes place at the limits of the intelligible defined by what Gadamer calls the remembrance of Language. Moreover, since the poem is made of words rather than subjective images or meanings, the distinctive poetic competence at work here is not that of individual creative genius making something from nothing. It is the capacity to listen into and listen out for the enigmatic movement of Language. The 
poet's attunement to Language, the capacity to allow the radical uncanniness of Language occurring in ordinary language to speak itself seems to be the core of this poetic sensibility (Cavell: 1988): 'The question is not whether the poets are silent, but whether our ear is acute enough to hear.' (Gadamer quoted in Bruns, 1997: 38, n.3). Here according to Gadamer 'the unpretentious thing evades thought most stubbornly.' (Bruns, 1997: 11). For the poet Paul Celan that poetic attunement is fundamentally corporeal. For Gadamer, and many others (Derrida: 1988), Celan is in fact the locus classicus of this phenomenon of the radical relation with the radically non-relation as it occurs in the encounter with speechlessness afforded paradoxically through the power of poetic words. The power of the poetic word, Agamben and Gadamer both agree, derives also from the way the poem combines both the semantic and the sonorific. The sign sounds as well as means. Hence the word is enfolded in manifold references of both rhyme and meaning. In the poem, however, rhyme ends without meaning being completed, and the poem 'tenaciously lingers and sustains itself in the tension and difference between sound and sense, between the metrical series and the syntactical series.' (Agamben,1999:112). It is important to note also here that the semantic (the word) and the a-semantic (homophony) are not strictly speaking two separate lines of parallel flight. They comprise instead the double intensity that animates Language and the sign, bearing witness to - keeping faith with - their undecidability: 'The structuring of sound, rhyme, rhythm, intonation, assonance, and so on, furnishes the stabilizing factors that haul back and bring to a standstill the fleeting word that points beyond itself (Gadamer quoted in Bruns: 6). 
'Compared with all other art forms,' Gadamer therefore writes, 'the poetic work of art possesses as Language a characteristic indeterminacy.' (Bruns, 1997: 37, n.2). The poetry of our time he adds has reached 'the limits of intelligible meaning and perhaps the greatest achievement of the greatest writers are themselves marked by a tragic speechlessness in the face of the unsayable.' (Bruns, 1997: 38, n.2). Auschwitz haunts this poetic sensibility. But the unspeakable that was Auschwitz becomes more broadly encompassed in a sensibility to the unsayable as such. The poem then becomes a means by which 'the speechless' can continue not only to address but also to move us. The radically non-relational quality to which post-structuralism's poetic sensibility attests is not then the word of God or the transcendental language of the gods. It is not occult, subterranean or otherworldly but is intimately related to an allied understanding of the experience of freedom in its relation to Language. I detect it in Foucault but it is explored intensely by Nancy in terms of the 'generosity' or 'prodigality' of what he calls 'the free dissemination of existence.' (Nancy: 1993: 13). Such freedom 'is existence deprived of essence and delivered to this inessentiality, to its own surprise as well as to its own decision, to its own indecision as well as to its own generosity.' (Nancy, 1993: 57). Elsewhere he addresses it as 'the invaluable' (Nancy: 1997). The change of bearing that the poetic word is said to effect - undergoing an experience with language - is also one said to give leeway to this freedom. Like many others, including perhaps most especially Derrida, Nancy is concerned with the peculiar bearing/responsibility (ethic) that this demands (Dillon: 1996). Celan, too, is explicit that poetry is not concerned with the category or concept of the beautiful or the sublime. In those sense it is not a work or a process of art. It is non-aesthetic. Its mode of being, its way or its ethos, is not that of 
oeuvre but of désoeuvrement or worklessness. Nacy adopts this idea directly in his account of community (Nancy, 1991). This movement of poetry is therefore not that of poetry alone and it is not directed toward a point of being finished. It is instead a ceaseless open-ended movement of indeterminacy toward what is always elsewhere. 'Not a movement of the true,' as Bruns pithily observes, 'but of freedom.' (Bruns, 1997: 19). Freedom from power-knowledge. Even, and perhaps especially, from complexity's power-knowledge of becoming. Poetry cuts us some slack from power: 'a breath for nothing.' (Rilke).

\section{Conclusion: Modern Odysseys}

The shamanistic figure of Orpheus, one of the great fertile poetic and religious myths of the western heritage, seems also to pervade the poetic sensibility of poststructuralism. For Orpheus, too, draws attention to the poetic as a medial way between modes or worlds, and to the poet as instrument; a liminal medium or Magus rather than all-powerful saviour or subjective genius. These features are powerfully recalled and recast by post-structural thinkers particularly for example by Blanchot (1982 a and b) and by Derrida (1981). In an almost classic post-structural motif, Blanchot refers directly, for example, to Orpheus as the 'identity of presence and absence' (McGahey: 138). Fleshy and corporeal, Celan's sense of 'being strung' like an instrument in and as this liminality also has a profoundly 'orphic' quality as well.

Gadamer called the poetic sensibility that I have just been discussing 'lyrical modernity'. If Orpheus was the lyricist, one of the most enduring songs of the western 
tradition is however that of the Odyssey. As Michael Shapiro recalls, this poem is a classic that continues to attract commentators who appropriate it as a vehicle for thinking about the problematics of order and of self-hood (Shapiro, 1992). Dante, for example, reworked it to reassess the working of God's will and of the human's search for salvation in a world shaped by Christian belief. His Odyesseus, perhaps influenced also by Virgil's somewhat hostile Latinisation of Ulysses, tells the tale of the unredeemed individual headed for destruction because of his scandalous insistence on crossing boundaries, and on his unwillingness to subordinate his desire to a higher power. Here the epic re-written as religious allegory serves to reinforce the message of the necessity of subordinating the self to a divine order. Joyce's re-working of the story re-opens the circle that Homer apparently closes with Odysseus' return to Ithaca. In a kaleidescope of individual adventures, framed as Hugh Kenner puts it as a 'space-time block of words', the narration of a personal adventure is transformed into a radical play of mutable meaning and significatory power (Kenner, 1987). In 'Silence of the Sirens', Kafka's characteristic preoccupation with the difficulty of discerning whether or not one is merely susceptible to summonses from outside or simply reproduces that summons within one's own consciousness is further explored through a re-telling of one of Odysseus' most memorable adventures. Horkeimer and Adorno transform Odysseus into a model property owner in the process of whose trashing they also indict the regime of 'regulative reason' enfolded within a myth of collective order for which, they say, the Odyssey stands (1972). Amongst less exalted appropriators, the behavioural political scientist Jon Elster invokes the Odyssey in order conversely to support his strategic, rationalistic and behavioural account of decision-making (1979). 
The Odyssey is a classic and unique example of oral poetry. In oral poetry performance and composition are one. Each rendition even by the same poet yields a new and different poem from the basic elements available in the tradition to the poet's recall. Oral poetry is therefore a process of re-composition in performance in ways comparable to the understanding of the continuous folding and unfolding of being-in-formation shared by complexity and post-structuralism. Subsequently written down, the Odyssey has nonetheless continued to escape definitive interpretation. The ordering of its narratives 'is elaborately non-linear.' (Slatkin, 1996: 223). It is 'open-ended, interpretatively ambivalent or indeterminate and irreducible to a single, straightforward, one-dimensional reading.' (Schein, 1996: 31). Whereas the action in the Iliad, by way of contrast, proceeds through a single narrative voice and in linear fashion from an unambiguous beginning, that of the Odyssey begins with two simultaneous actions proceeds through a number of narrative voices and traverses a whole variety of geographical, imaginary and fantastical terrains. The hero himself only enters the scene in Book 5 effecting yet another beginning. The poem then proceeds to move back and forth giving us the simultaneous perspectives of many time frames and many locations. Polyvocal and poytropic its topics are polymorphality and polyphenomenality. The complexity of its structure combines with its ambiguous ending powerfully to suggest that the poem's message is ultimately undecidable (Schein, 1996: 31). ${ }^{1}$ Arguably, the poem might ultimately be said to concern undecidability as such.

\footnotetext{
${ }^{1}$ In the epic sequel to the Odyssey entitled the Telegony, Odysseus' further adventures included journeys, wars, a second marriage to Kallidike, Queen of the Thesprotians, and death at the hands of Telegonos, his son by Kirke. In the Odyssey itself, Odysseus having regained his home in Ithaca nonetheless also tells his wife Penelope of the "immeasurable toil there will still be in the future,/ toil abundant and difficult that it is necessary for me to finish completely." (23.249-50). Schein, 1998: 26n.
} 
The theme of oral poetry - and in particular that of the Odyssey - does not have a single pure form either for the individual singer or for the tradition as a whole:

Its form is ever changing in the singer's mind because the theme in reality is protean; in the singer's mind it has many shapes, all the forms in which he has ever sung it. It is not a static entity, but a living, changing, adaptable artistic creation.

Yet it exists for the sake of the song.' (Slatkin, 1996, quoting Singer of Tales: 226) Returning to the Odyssey thus serves to recall finally, here, that the structure of the poetic has in many ways always been a discourse of 'complexity', as it were avant la lettre. It, too, concerns what it means to be human in a world of radical relationality. But what most differentiates the Odyssey from its rival epic, the Iliad, is not only the more complex structures of the Odyssey - indeed its very non-linear complexity - but the entirely different virtue that it extols (Schein, 1996). The overwhelming fact of life for the warrior heroes of the Iliad is their mortality. This stands in contrast to the immortality of the gods. Such an acute sense of mortality prompts the warriors to risk an early death in battle. They do so in order to achieve the 'imperishable glory' of poetic remembrance. Heroes of songs that will keep their names and achievements alive they seek thereby to transcend mortality's ephemeral existence through being poeticised. Idealising the heroic way of life the Iliad nonetheless also invites its readers to critically review its tragic and contradictory character. By contrast the Odyssey is an account of one who continuously cheats death seeking to navigate his way through a post-war world where the options are more diverse and complex than those of the Iliad. Unlike Achilles, Odysseus is the exemplar of the survivor. He continuously overcomes the trials and tribulations of his wanderings and the threats of his enemies. Heroic excellence is redefined here in terms of 
continuous survival, homecoming and the peculiar form of strategic intelligence (metis) by which Odysseus secures himself in a world of indeterminacy and change where the rule of survival has to be found in the contingent circumstances of shifting encounters, terrains and temporalities.

Above all the Odyssey appears to be a story of homecoming, of returning successfully to a terminus from whence one originally departed. But how could the Greeks, who knew that one never enters the same river twice, believe in any final homecoming? Odysseus does not return home for good, or ill, but to set off again. His story is a story of motion. Motion both purposeful and purposeless, successful and futile, changing yet unchanging. It is a motion that is not the mere movement of objects in space but the always already being underway, transitivity continuously experiencing transformation, that comprises the freedom of mortality itself (Bernard Schlink, 1997, The Reader: 179-180). One might therefore ask for the sake of what ethic in respect of this motility do the rival epics of complexity and post-structuralism sing their different songs? Posing this question dramatises the issue of the different way of life to which each subscribes. Knowledge of morphogenesis, intelligence, survival, flexibility and ultimately fitness for complexity. Alterity, differànce, undecidability, responsibility, and ultimately justice for post-structuralism (Dillon, 1999). 


\section{$\underline{\text { References }}$}

Adorno, Theodor and

Horheimer, Max (1972) ～Dialectic of Enlightenment. London: Verso.

Agamben, Giorgio (1991) Language and Death. The Place of

Negativity. Minneapolis: Minnesota University Press.

Agamben, Giorgio (1998) Homo Sacer.. Stanford: Stanford University

Press

Alberts, David S. and

Czerwinski, Thomas (1997) Complexity, Global Politics and National

Security. Washington: National Defence University.

Ansell-Pearson, K. (1997) Deleuze and Philosophy. London: Routledge.

Ansell-Pearson, K. (1997) Viroid Life. London: Routledge.

Ansell-Pearson, K. (1999) Germinal Life. London: Routledge.

Baumard, Philippe (1993) "Learned Nations," Private paper

Bernasconi, Robert (1985) The Question of Language in Heidegger's History of Being.

Atlantic Highlands, New Jersey: Humanities Press.

Blanchot, Maurice (1982a) The Space of Literature. Lincoln: University of Nebraska Press.

Blanchot, Maurice (1982b) The Siren's Song. Bloomington: Indiana University Press.

Blanchot, Maurice (1993) The Infinite Conversation. Minneapolis: University of Minnesota Press.

Bogard, William (1996) The Simulation of Surveillance. Hypercontrol in Telematic 
Societies. Cambridge: Cambridge University Press.

Bohm, David (1980)

Butler, Judith (1997a)

Butler, Judith (1997b)

Cavell, Stanley (1988)

Cebrowski, Arthur and

Gartska, John (1998)

Chia, Robert (1994)

Chia, Robert (1995)

Chia, Robert (1996)
Wholeness and Implicate Order. London: Routledge.

Excitable Speech. A Politics of the Performative. London:

Routledge.

The Psychic Life of Power. Stanford, California: Stanford University Press.

In Quest of the Ordinary: Lines of Skepticism and

Romanticism. Chicago: Chicago University Press.

"Network-centric Warfare: Its Origins and Future." United

States Naval Institute Proceedings,.

Czerwinski, Thomas (1997) Coping with Bounds. Speculations on Non-Linearity in Military Affairs. Washington: National Defense University.

"The Concept of Decision a Deconstructive Analysis,"

Journal of Management Studies 31 (6).

"From Modern to Postmodern Organisational Analysis," Organisation Studies 16 (4).

"Teaching Paradigm Shifting in Management Education:

University Business Schools and the Entrepreneurial

Imagination," Journal of Management Studies 33 (4).

Connolly, William (1993) The Augustinian Imperative. London: Sage.

Cilliers, Paul (1998)

Complexity and Postmodernism. London: Routledge.

Critchley, Simon (1997) Very Little...Almost Nothing. Death, 
Philosophy, Literature. London: Routledge.

de Landa, Manuel (1991) War in the Age of Intelligent Machines.

New York: Zone Books.

de Landa, Manuel (1997) A Thousand Years of Non-Linear History. New York:

Swerve Editions.

Deleuze, Gilles (1988) Spinoza. Practical Philosophy. San Francisco: City Lights.

Deleuze, Gilles (1990) The Logic of Sense. New York: Columbia UP.

Deleuze, Gilles (1991)Ｂergsonism. New York: Zone Books.

Deleuze, Gilles (1993) The Fold. London: Athlone.

Deleuze, Gilles (1994) Difference and Repetition. London: Athlone.

Deleuze, Gilles (1992) "Postscript on the Societies of Control." October 59: 3-7.

Derrida, Jacques (1974) Of Grammatology. Baltimore: The Johns Hopkins

University Press.

Derrida, Jacques (1981) Dissemination. Chicago: Chicago University Press.

Derrida, Jacques (1981) "Plato's Pharmacy," in, Dissemination. Chicago: University of Chicago Press.

Derrida, Jacques (1988a) Schibboleth. Pour Paul Celan. Paris: Galilé.

Derrida, Jacques (1988b)～～Limited Inc. Evanston, Ill.: Northwestern University Press.

Derrida, Jacques (1992) "Force of Law: The 'Mystical Foundations of Authority,"' in Drucilla Cornell et al, eds., Deconstruction and The Possibility of Justice. London: Routledge.

Derrida, Jacques (1993) Aporias. Stanford: Stanford University Press. 
Derrida, Jacques (1994) "Nietzsche and the Machine. Interview with Richard Beardsworth," Journal of Nietzcshe Studies 7 (Spring).

Derrida, Jacques and

Vattimo, Gianni (1998) Religion. Cambridge: Polity.

Dillon, Michael (1995) "Paradosis," Journal of the British Society for

Phenomenology, 26 (3): 229-239.

Dillon, Michael (1996) Politics of Security. Towards a Political

Philosophy of Continental Thought. London: Routledge.

Dillon, Michael (1999) “Another Justice,” Political Theory, 27 (2): 155-175

Elster, John (1979) Ulysses and the Sirens: Studies in Rationality and

Irrationality. Cambridge: Cambridge University Press.

Foti, Veronique (1992) Heidegger and The Poets.

Poiesis/Techne/Sophia. New Jersey: Humanities Press.

Foucault, Michel (1975) The Birth of the Clinic. New York: Vintage Books.

Foucault, Michel (1977) Language, Couter-Memory, Practice. Ithaca: Cornell

University Press.

Foucault, Michel (1979) Discipline and Punish. New York: Vintage Books .

Foucault, Michel (1980) Herculine Barbin: Being the Recently Discovered

Memoires of a Nineteenth Century French Hermaphrodite.

New York: Random House.

Foucault, Michel (1989) The Order of Things. London: Routledge.

Gordon, Colin, ed. (1980) Michel Foucault. Power/Knowledge. Brighton: The

Harvester Press. 
Heidegger, Martin (1962) Being and Time. Oxford: Blackwell.

Heidegger, Martin (1971a) On The Way To Language. San Francisco: Harper and Row.

Heidegger, Martin (1971b) Poetry, Language and Thought. New York: Harper and Row.

Heidegger, Martin (1973) The End of Philosophy. New York: Harper and Row.

Heidegger, Martin (1995) The Fundamental Concepts of Metaphysics. Bloomington: Indiana University Press.

Heidegger, Martin (1977) The Question Concerning Technology and Other Essays.

New York: Harper and Row.

Jervis, Robert (1997) System Effects. Complexity in

Political and Social Life. Princeton: Princeton University

Press.

Kay, Lily E. (1993) The Molecular Vision of Life. Caltech, The Rockefeller

Foundation and the Rise of the New Biology. New York:

Oxford University Press.

Kempis, G.K. (1991) Self-Modifying Systems in Biology and Cognitive Sciences.

Oxford: Pergammon.

Kenner, 1987

Lacoue-Labarthe, Philippe and Nancy, J-L (1988) The Literary Absolute. The Theory of Literature in German Romanticism. Albany: SUNY.

Levinas, Emmanuel (1998) Of God Who Comes to Mind. Stanford: Stanford 
University Press.

McGahey, Robert (1994) The Orphic Moment. Shaman to Poetic Thinker in Plato,

Nietzsche and Mallarmé. Albany: SUNY.

Nancy, Jean-Luc (1991) The Inoperative Community. Minneapolis: Minnesota

University Press.

Nancy, Jean-Luc (1993) The Experience of Freedom. Stanford: Stanford University

Press.

Nancy, Jean-Luc (1997) “The Insufficiency of 'Values' and the Necessity of

'Sense'," Cultural Values, 1 (1): 127-131.

Nietzsche, F (1989)

On the Genealogy of Morals and Ecce Homo. New York:

Vintage Books.

Patton, Paul (1996)

Deleuze: A Critical Reader. Oxford:

Blackwell.

Poster, Mark (1990) The Mode of Information. Cambridge: Polity Press.

Poster, Mark (1995) The Second Media Age. Cambridge: Polity Press.

Prigogine, I (1980) From Being to Becoming. San Francisco: Freeman.

Pucci, Pietro (1996) Odusseus Polutropos: Intertextual Readings in the Odyssey

and the Illiad. Ithaca: Cornell University Press.

Pucci, Pietro (1998) The Song of the Sirens. Essays on Homer. New York:

Rowman and Littlefield.

Rabinow, Paul (1996a) Essays on the Anthropology of Reason. Princeton, N.J.:

Princeton University Press. 
Rabinow, Paul (1996b)

Making PCR. A Story of Biotechnology. Chicago; Chicago

University Press.

Rancière, Jacques (1999) Dis-agreement. Minneapolis: Minnesota University Press.

Ritvo, Harriet (1998) The Platypus and the Mermaid. Harvard: Harvard

University Press.

Rose, Nikolas (1999) Powers of Freedom. Cambridge: Cambridge University

Press.

Serres, Michel (1982)

Hermes. Literature, Science and Philosophy. Baltimore:

The Johns Hopkins University Press.

Schein, Seth, L., ed. (1996) Reading the Odyssey. Princeton: Princeton University

Press.

Shapiro, Michael J. (1992) The Postmodern Polity. Minneapolis: Minnesota University

Press.

Slatkin, Laura (1996) "Composition by Theme and the Mètis of the Odyssey," in

Schein, ed., Reading the Odyssey.

Stengers, Isabelle (1997) Power and Invention. Situating Science.

Minneapolis: Minnesota University Press.

Stiegeler, Bernard (1998) Technics and Time. Volume 1. Stanford: Stanford

University Press.

Taminiaux, Jacques (1993) Poetics, Speculation and Judgement. The

Shadow of the Work of Art from Kant to Phenomenology.

Albany: SUNY.

Taylor, Mark C. (1995) "Rhizomatic Fields of Interstanding," 
Tekhnema, 2.

Vattimo, Gianni (1992) The Transparent Society. Cambridge: Polity.

Villa, Dana (1997) Arendt and Heidegger. Princeton: Princeton University

Press. 